\title{
OS FUNDAMENTOS DA AUTONOMIA PARA O SUPREMO TRIBUNAL FEDERAL NOS JULGAMENTOS DA ADPF 54 E DO HC 124.306
}

\author{
THE FUNDAMENTALS OF AUTONOMY FOR THE BRAZILIAN \\ SUPREME FEDERAL COURT AT THE ADJUCATED OF THE CLAIM \\ FOR NON-COMPLIANCE OF BASIC PRINCIPLES (ADPF) 54 AND \\ THE HABEAS CORPUS (HC) 124.306
}

Janaína Reckziegel'

Cassiane Wendramin ${ }^{2}$

\begin{abstract}
RESUMO: A análise da Arguiçăo de Descumprimento de Preceito Fundamental n. 54 e do Habeas Corpus n. 124.306, ambos do Supremo Tribunal Federal, foi realizada com o objetivo de extrair dos julgados as pontuaçôes relevantes dos Ministros no tocante à conceituaçâo de autonomia como argumento principal dos votos, diante da possível colisáo do direito à vida do feto e da autonomia da gestante e verificar se as definiçóes de autonomia apostas pelos julgadores referem-se à compreensâo de autonomia privada. Procedeu-se uma pesquisa teórica, pautada no método de estudo de caso, que, utilizando-se da metodologia analítica, examinou inicialmente as definiçóes de autonomia dispostas pelos julgadores que formaram suas razóes decisórias. Como resultado da presente pesquisa, concluiu-se que para a Corte a autonomia da gestante prevalece ao direito à vida do feto anencefálico ou até o primeiro trimestre gestacional, diante da inviabilidade de vida extrauterina desses fetos, detectando-se que para comporem o conceito de autonomia das razóes de decidir, os julgadores pautaram-se na definiçăo de autonomia privada.
\end{abstract}

PALAVRAS-CHAVE: Autonomia. Autonomia Privada. Interrupçăo da Gestaçăo. Supremo Tribunal Federal.

1 Doutora em Direitos Fundamentaise Novos Direitos pela Universidade Estácio de Sá; Mestre em Direito Público; Especialista em "Mercado de trabalho e exercício do magistério em preparaçâo para a Magistratura" e em "Educaçâo e docência no ensino superior". Graduada em Ciências Jurídicase Sociais pela Universidade do Oeste de Santa Catarina. Professora e Pesquisadora da Universidade do Oeste de Santa Catarina. Advogada e Professora Universitária.E-mail: janaina.reck@gmail.com

2 Mestranda em Direito na Universidade do Oeste de Santa Catarina - UNOESC, Chapecó/SC, linha de pesquisa Direitos Fundamentais Civis: A Ampliaçāo dos Direitos Subjetivos. Advogada. Professora Universitária.E-mail: cassi.wen@hotmail.com. 
ABSTRACT: The analysis of the Claim for Non-Compliance of Basic Principle number 54 and the Habeas Corpus number 124.306, both of the Supreme Federal Court, was carried out with the objective of extract from the adjucated the relevant Ministers' points regarding the conceptualization of autonomy as the main argument of the votes, in view of the possible collision of the fetus' right to life and the autonomy of the pregnant woman and to verify if the definitions of autonomy placed by the judges refer to the understanding of private autonomy. A theoretical research, based on the case study method, was carried out, which, using the analytical methodology, initially examined the definitions of autonomy placed by the judges who formed their reasons for decision. As a result of this research, it was concluded that for the Court the autonomy of the pregnant woman prevails on the right to life of the anencephalic fetus or until the first gestational quarter, in view of the unviability of extrauterine life of these fetuses, finding that, in order to compose the concept of autonomy of the reasons for deciding, the judges were based on the definition of private autonomy.

KEYWORDS: Autonomy. Private Autonomy. Interruption of the Pregnancy. Brazilian Supreme Federal Court.

\section{INTRODUÇÃO}

A repulsa social e moral que gera a descontinuaçăo da gestaçăo mediante um ato unilateral da gestante ocorre pela colisăo entre direitos humanos fundamentais, de um lado o direito à vida do feto e, de outro, a autonomia da gestante.

E nâo é novidade a discussấo social sobre o assunto, notadamente porque para alguns, a gestante sofre física e psicologicamente ao manter uma gestaçấo na qual o feto năo viverá extrauterinamente, como no caso da anencefalia e, para outros, năo é dado o poder de decisăo antecipadamente a outrem a respeito da vida do próprio feto, uma vez que, mesmo que por pouco tempo, poderá existir vida nesse feto.

Exatamente por conta dessa aparente violaçâo a direitos fundamentais é que a Corte Suprema brasileira foi instada a se manifestar em duas situaçôes específicas - e consideradas as principais para o assunto - a interrupçấo da gravidez de feto anencefálico (ADPF 54) ou até o primeiro trimestre da gestaçăo (HC 124.306), marcadas como uma das mais importantes analisadas pelo Tribunal, de modo que manifesta a importância da análise dos precedentes e do posicionamento da corte em relaçăo à temática, porquanto evidencia a tensâo existente entre os direitos colidentes.

Justamente por isso, e com a intençăo de analisar os argumentos delineados pelo Supremo Tribunal Federal em relaçáo à concepçâo de autonomia, pautando-se no método de estudo de caso e utilizando-se a metodologia analítica, é que se procedeu ao exame da Arguiçăo de Descumprimento de Preceito Fundamental n. 54 e do Habeas Corpus n. 124.306.

Desse modo, a primeira parte do trabalho analisa o conteúdo fático dos precedentes, traçando uma narrativa didática acerca dos julgados, enfatizando-se pontos relacionados à autonomia e direitos fundamentais, para, na sequência, contextualizar especificamente as razōes jurídicas de decidir aventadas nos casos em análise, notadamente quanto aos argumentos relacionados ao tema em voga - autonomia. 
Por fim, a partir do referencial teórico kantiano de dignidade da pessoa humana e autonomia, pondera-se a conceituaçáo de autonomia visando detectar se as definiçóes de autonomia utilizadas pelo Supremo Tribunal Federal nos casos analisados enquadram-se à concepçăo dogmática de autonomia privada, já que a Corte entendeu, em sua maioria e consubstanciada nas influências do Ministro Luís Roberto Barroso, que prevalece a autonomia da gestante para decidir livremente sobre a interrupçâo ou nâo da gestaçăo anômala, diante da inviabilidade de vida extrauterina do feto, tanto na anencefalia quanto durante o primeiro triênio gestacional, inferindo-se que, apesar de o termo "autonomia privada" náo constar expressamente nos julgados, intrínseca e substancialmente está disposta nas razôes de decidir.

\section{EXPOSIÇÃO SUMÁRIA DOS JULGADOS DOS SUPREMO TRIBUNAL FEDERAL - ADPF 54 E HC 124.306}

Com o objetivo de contextualizar didaticamente os precedentes que compóem o presente trabalho, necessária a separaçáo em ordem cronológica e individual dos julgados, para que seja possível enfatizar os argumentos relacionados à autonomia e direitos fundamentais que se encontram em cada um deles. Ressalta-se, no entanto, que sobressaindo as questôes envolvendo a autonomia năo significa considerar de somenos importância os demais argumentos lançados nas razōes de decidir de cada julgador, porém, em virtude da temática proposta no trabalho, importante salientar aqueles que têm conexâo com o tema.

\subsection{A DESCONTINUAÇĂO DA GESTAÇĂO DE FETO ANENCEFÁLICO - ADPF N. 54}

Em 17 de junho de 2014, a açâo constitucional proposta pela Confederaçăo Nacional dos Trabalhadores na Saúde, representada à época pelo (ex-)advogado Luís Roberto Barroso, visou declarar a inconstitucionalidade, com eficácia erga omnes e efeito vinculante, da interpretaçăo dos artigos 124, 126 e 128, incisos I e II, todos do Código Penal ${ }^{3}$ (BRASIL, 1940), nos casos de antecipaçăo terapêutica da gestaçâo de feto anencefálico, previamente diagnosticada por profissional habilitado, buscando garantir o direito subjetivo da gestante de interromper a gravidez, nesse caso sem a necessidade de prévia autorizaçăo judicial ou permissâo estatal para tal fim.

As razóes lançadas no petitório envolviam os preceitos fundamentais dispostos nos artigos $1^{\circ}$, inciso IV (dignidade da pessoa humana); $5^{\circ}$, inciso II (princípio da legalidade, liberdade e autonomia da vontade); $6^{\circ}$, caput, e 196 (direito à saúde), todos da

3 Art. 124 - Provocar aborto em si mesma ou consentir que outrem lho provoque: Pena - detençâo, de um a três anos.

Art. 126 - Provocar aborto com o consentimento da gestante: Pena - reclusăo, de um a quatro anos.

Parágrafo único. Aplica-se a pena do artigo anterior, se a gestante náo é maior de quatorze anos, ou é alienada ou débil mental, ou se o consentimento é obtido mediante fraude, grave ameaça ou violência.

Art. 128 - Năo se pune o aborto praticado por médico:

Aborto necessário: I - se náo há outro meio de salvar a vida da gestante;

Aborto no caso de gravidez resultante de estupro: II - se a gravidez resulta de estupro e o aborto é precedido de consentimento da gestante ou, quando incapaz, de seu representante legal. (BRASIL, 1940). 
Carta da República, à medida que o Poder Público, investido da funçăo judicante (juízes e tribunais), estava interpretando os artigos do Código Penal (124, 126 e 128, I e II) sem considerar os princípios fundamentais, considerando a conduta de interrupçăo de gestaçăo de feto anencéfalo como penalmente típica.

O principal argumento dos pedidos embasava-se na inviabilidade de vida extrauterina do feto anencéfalo que, segundo comprovaçăo médica, possui remota possibilidade de sobrevivência, de modo que a conduta da interrupçăo de feto com a anomalia náo se subsumiria ao tipo penal do aborto, pois năo haveria vida, bem jurídico tutelado pela norma incriminadora. Contrapunha-se a proteçâo do direito à preservaçâo da vida do nascituro com a liberdade e autonomia da gestante.

O relator do caso, Ministro Marco Aurélio, liminarmente concedeu năo somente o sobrestamento dos processos e decisôes năo transitadas em julgado, como também reconheceu ad referendum o direito constitucional da gestante de submeter-se a procedimento de descontinuaçấo da gestaçăo de feto anencefálico a partir de laudo médico atestando a anomalia. Apesar disso, no ano seguinte sua decisăo foi revisada pelo pleno Tribunal, o qual manteve a suspensăo do andamento dos processos e decisôes năo definitivas, reformando o ponto que permitiu o aborto de fetos anencefálicos.

Somente 8 (oito) anos após o ajuizamento da açăo, em 12 de abril de 2012, é que o plenário da corte analisou e julgou definitivamente a ADPF 54, obtendo-se, na ocasiăo, 8 (oito) votos favoráveis à procedência do pedido, dos Ministros Marco Aurélio, Luiz Fux, Gilmar Mendes, Carlos Ayres Brito, Celso de Mello, Rosa Weber, Carmen Lúcia e Joaquim Barbosa, permitindo-se a interrupçăo da gestaçâo; 2 (dois) votos pela improcedência, manifestados pelos Ministros Cezar Peluso e Ricardo Lewandowski; e 1 (um) voto, do Ministro Dias Toffoli, que se declarou impedido diante de sua atuaçáo na Advocacia-Geral da Uniăo.

O julgamento abordou um tema conflituoso tanto para o direito quanto para a sociedade e também impulsionou a corte suprema a se posicionar juridicamente para definir o alcance constitucional do conceito de vida e sua tutela normativa. Do acórdáo de relatoria do Ministro Marco Aurélio depreendem-se alguns pontos que merecem destaque:

I. A preocupaçăo dos juristas em definir o conceito de aborto, que está ligado à interrupçấo da gestaçăo de feto sadio, situaçăo diversa quando se trata de feto anômalo;

II. O esforço para fundamentar os conceitos de anencefalia e vida, já que sâo contraditórios, porquanto o anencéfalo nâo tem potencialidade de vida diante da ausência total ou parcial do encéfalo, parte superior do sistema nervoso central que controla o organismo, de modo que o conflito entre direitos fundamentais (direito à vida e dignidade da mulher) é apenas aparente;

III. Ainda, porque a Constituiçăo Federal tutela o indivíduo enquanto pessoa, o feto anencéfalo năo teria especial proteçăo estatal, uma vez que năo há potencialidade de vida extrauterina, e, supondo-se que existisse, essa vida nâo ultrapassaria algumas horas, motivo pelo qual, em uma hipótese de conflito, prevaleceriam os direitos à dignidade, liberdade, autodeterminaçấo, saúde, 
sexuais e reprodutivos da mulher, diante da perpetuidade deles, argumentos embasados na ADI n. 3.5104;

IV. Concluiu-se, por fim, pela inconstitucionalidade da interpretaçấo de que a descontinuidade da gestaçăo de feto anencefálico se amolda à conduta típica dos artigos 124, 126 e/ou 128, incisos I e II, todos do Código Penal (MELLO; BARBOZA, 2015).

Infere-se, assim, a preocupaçâo da corte em delinear o objeto analisado juridicamente visando evitar que aquela decisăo fosse capaz de servir como precedente para uma futura possível descriminalizaçăo do aborto, deixando claro desde o início que se lidava com a inviabilidade de vida futura do anencefálico, o qual, na remota hipótese de conseguir nascer, sobreviveria por apenas algumas horas.

\subsection{ABORTO REALIZADO NO PRIMEIRO TRIMESTRE GESTACIONAL - HABEAS CORPUS 124.306}

A análise pelo Supremo Tribunal Federal do HC 124.306, ao contrário do que ocorreu na ADPF 54, deu-se a partir de um processo jurídico criminal, no qual Edilson dos Santos e Rosemere Aparecida Ferreira, que mantinham uma clínica de aborto na cidade de Duque de Caxias/RJ, foram presos em flagrante, em 14 de março de 2013, por infringirem os dispositivos dos artigos 126 (aborto provocado por terceiro) e 288 (quadrilha ou bando à época, atual associaçăo criminosa), ambos do Código Penal.

Em razâo da prisăo, as partes requereram a concessăo de liberdade provisória, a qual foi deferida pelo juízo da $4^{\mathrm{a}}$ Vara Criminal sob o argumento de que as infraçóes eram de médio potencial ofensivo e, logo, permitiriam a conversăo em penas restritivas de direitos de regime aberto. Apesar disso, o Ministério Público estadual interpôs recurso em sentido estrito ${ }^{5}$ que foi provido pela $4^{\text {a }}$ Câmara Criminal do Tribunal de Justiça do Estado do Rio de Janeiro, em 25 de fevereiro de 2014, e, por consequência, expediram-se os mandados de prisăo.

Os acusados entâo impetraram habeas corpus no Superior Tribunal de Justiça (HC n. 290.341), o qual foi indeferido liminarmente (BRASIL, 2014). A defesa buscou a proteçăo da liberdade de locomoçăo dos pacientes em novo pedido de habeas corpus agora

4 A ADI n. 3.510 questionou a constitucionalidade da permissăo de pesquisas com células-tronco embrionárias, oportunidade em que o STF teve que delimitar qual o conteúdo e a extensâo do direito à vida e à dignidade da pessoa humana, concluindo pela constitucionalidade do art. $5^{\circ}$, seus incisos e parágrafos, da Lei n. 11.105/2005 Lei de Biossegurança), desde que seja interpretado no sentido de que a permissăo da pesquisa e terapia com células-tronco embrionárias, obtidas de embriôes humanos produzidos por fertilizaçáo in vitro, deve ser condicionada à prévia autorizaçăo e aprovaçăo por Comitê (Órgão) Central de Ética e Pesquisa, vinculado ao Ministério da Saúde. Pontuou-se no acórdāo que: "Mas as três realidades náo se confundem: o embriâo é o embriăo, o feto é o feto e a pessoa humana é a pessoa humana. Donde nâo existir pessoa humana embrionária, mas embriâo de pessoa humana. O embriăo referido na Lei de Biossegurança ('in vitro' apenas) năo é uma vida a caminho de outra vida virginalmente nova, porquanto lhe faltam possibilidades de ganhar as primeiras terminaçōes nervosas, sem as quais o ser humano náo tem factibilidade como projeto de vida autônoma e irrepetível. O Direito infraconstitucional protege por modo variado cada etapa do desenvolvimento biológico do ser humano. Os momentos da vida humana anteriores ao nascimento devem ser objeto de proteçấo pelo direito comum. $\mathrm{O}$ embriāo pré-implanto é um bem a ser protegido, mas nâo uma pessoa no sentido biográfico a que se refere a Constituiçẫo." (BRASIL, 2008).

Autos n. 0065502-27.2013.8.19.0000. 
no Supremo Tribunal Federal, que originou o precedente em análise (HC n. 124.306), e, liminarmente, o Ministro relator Marco Aurélio deferiu o pedido concedendo liberdade aos réus até o julgamento final do processo.

No julgamento de mérito, presentes à sessăo os Ministros Marco Aurélio, Luiz Fux, Rosa Weber, Edson Fachin e Luís Roberto Barroso. Em voto-vista dos autos, o Ministro Barroso inicialmente manifestou-se no tocante ao habeas corpus, entendendo pela ausência dos requisitos autorizadores da custódia. No entanto, foi além e adentrou na inconstitucionalidade da criminalizaçâo da interrupçâo voluntária da gestaçâo efetivada no primeiro trimestre, ao argumento de que "para ser compatível com a Constituiçấo a criminalizaçâo de determinada conduta exige que esteja em jogo a proteçâo de um bem jurídico relevante, que o comportamento incriminado nâo constitua exercício legítimo de um direito fundamental e que haja proporcionalidade entre a açăo praticada e a reaçâo estatal." (BRASIL, 2016, p. 12).

A Ministra Rosa Weber, em voto concorrente, também se manifestou especificamente no que diz respeito ao ponto da inconstitucionalidade, pontuando que cabe interpretaçăo conforme a Constituiçăo para excluir do âmbito de incidência dos artigos 124 a 126 a hipótese de interrupçăo voluntária da gravidez, por decisâo da mulher, no primeiro trimestre.

Vencido o voto do Ministro Marco Aurélio quanto à admissâo do habeas corpus, a Primeira Turma do Supremo Tribunal Federal, sob a presidência do Ministro Luís Roberto Barroso, entendeu, por maioria, pelo descabimento do habeas corpus como substitutivo do recurso ordinário constitucional, justamente pela inadequaçấo da via eleita, contudo, de ofício, afastou a custódia preventiva, inicialmente porque náo se encontravam preenchidos os requisitos autorizadores do artigo 312 do Código de Processo Penal e, além disso, pela inconstitucionalidade da incidência do tipo penal do aborto na descontinuidade da gestaçâo no primeiro trimestre.

Nâo é demais mencionar que, apesar de ter sido uma decisâo isolada e, portanto, sem efeito erga omnes nem vinculante, o fato é que impinge à sociedade mudanças, tanto é que, como bem apontado por Steinmetz e Reckziegel (2017, p. 764), serviu de influência ao Partido Socialismo e Liberdade (PSOL) para o ajuizamento da Arguiçáo de Descumprimento de Preceito Fundamental n. $442^{6}$ que objetiva que o Supremo Tribunal Federal "declare a nâo recepçăo parcial dos artigos 124 e 126, do Código Penal, para excluir do seu âmbito de incidência a interrupçăo da gestaçăo induzida e voluntária realizada nas primeiras 12 (doze) semanas."

Os principais pontos do precedente em análise foram salientados com o objetivo de ressaltar exatamente em quais argumentos a temática se pautará e, notadamente, examinará as questōes jurídicas envolvendo os conflitos entre direitos apontados nos julgados.

Na petiçăo inicial desta arguiçâo de descumprimento de preceito fundamental, a parte autora requereu, ao argumento de que presentes os requisitos da plausibilidade do direito (fumus boni juris) e do perigo da demora (periculum in mora), a concessáo de medida cautelar para: (i) suspensáo das prisóes em flagrante, inquéritos policiais e andamento de processos ou efeitos de decisóes judiciais que pretendam aplicar ou tenham aplicado os artigos 124 e 126 do Código Penal a casos de interrupçâo da gestaçáo induzida e voluntária realizada nas primeiras 12 semanas de gravidez; (ii) reconhecimento do direito das mulheres de interromper a gestaçăo e dos profissionais de saúde de realizar o procedimento (BRASIL, 2017). 


\section{ARGUMENTOS JURÍDICOS DOS JULGADOS RELACIONADOS À AUTONOMIA}

Para fundamentar os argumentos dos precedentes citados, os julgadores nâo se pautaram apenas na dignidade da pessoa humana e autonomia e, diante disso, faz-se necessária a contextualizaçâo jurídica dos fundamentos dos julgados, deixando para este momento a análise dos pressupostos que tocam a discussăo e posicionamento do órgáo a respeito dos direitos fundamentais em voga, a iniciar, cronologicamente, pela ADPF 54.

\subsection{DISCUSSĂO DO DIREITO À VIDA VERSUS LIBERDADE E AUTONOMIA DA MULHER NA ADPF 54}

Primeiramente deve-se relevar o fato de que năo há na legislaçâo brasileira um comando normativo que define o início da vida, ao contrário, tal conceito é discutível inclusive quando se trabalha a doutrina médica, e, além disso, para que se possa falar em direito à vida é necessário analisar se para os fetos anencefálicos há ou nâo o início da vida.

Nesse ponto da discussâo, os ministros náo chegaram a um consenso. Alguns definiram que para que haja vida se faz necessária a existência de atividade cerebral. Outros, entenderam indispensável a potencialidade de vida extrauterina. E, ainda, a Ministra Rosa Weber aludiu à capacidade do indivíduo em fazer parte do convívio social.

O conceito de morte cerebral, adotado pela Lei n. 9.434/977 é a razăo de ser do argumento da atividade cerebral relevado por alguns ministros, segundo o qual haverá morte encefálica quando inexistir atividade cerebral. Ocorre que, conforme aduziram os Ministros Gilmar Mendes e Cezar Peluso, morte encefálica e anencefalia săo distintas, cuja diferença reside no fato da autonomia cardíaca e respiratória que o indivíduo possui mesmo sendo anencéfalo, enquanto que na morte encefálica a pessoa só permanece viva com auxílio de aparelhos.

Por sua vez, para o Ministro Marco Aurélio, a potencialidade de vida extrauterina seria uma espécie de conceito biológico, enquanto que o Ministro Joaquim Barbosa entendeu como sendo uma definiçâo jurídica, complicando ainda mais a delimitaçâo. Fato é que, em que pese a dissonância entre os posicionamentos para definir "vida", prevaleceu como tese defendida o năo reconhecimento de vida ao feto anencéfalo por nâo possuir vida extrauterina viável.

Infere-se, portanto, do precedente que a maioria dos ministros entendeu que a proibiçâo do aborto se faz necessária à medida que se deve proteger a potencialidade de vida extrauterina. Todavia, a proteçâo do direito à vida comporta gradaçôes, de modo que possibilitam desqualificar a proteçăo à vida do feto anencéfalo pelo fato de năo ser pessoa humana ou năo estar no grau de desenvolvimento completo, quando entấo, na ponderaçáo, faz-se prevalecer os direitos da mulher.

7 Dispóe sobre a remoçáo de órgâos, tecidos e partes do corpo humano para fins de transplante e tratamento. 
Verifica-se entăo que năo se está em colisăo direta o direito à vida e os direitos da gestante, já que, sendo o feto anencéfalo, năo haverá vida extrauterina em potencial, e, entăo, o conflito é "apenas aparente entre direitos fundamentais. Em rigor, no outro lado da balança, em contraposiçăo aos direitos da mulher, năo se encontra o direito à vida ou à dignidade humana de quem está por vir, justamente porque năo há ninguém por vir, năo há viabilidade de vida." (BRASIL, 2012, p. 54).

Marchiori (2012, p. 44), nesse sentido, sintetizou (muito bem) os argumentos de ponderaçâo dos ministros, e concluiu que "[...] nenhum decidiu exclusivamente com fundamento numa ponderaçấo pura e simples entre a vida do feto anencéfalo e os direitos à liberdade, autonomia, privacidade e direitos reprodutivos da mulher." Dentre as decisōes, pôde-se verificar que "(i) se considerou inexistente a vida biológica e/ou jurídica desse feto, năo havendo óbice para proibir a mulher de interromper a gravidez e exercer seus direitos - nesse caso nem haveria ponderaçâo"; ainda, "(ii) se reconheceu a vida, mas como merecedora de tutela jurídica menos intensa, daí a ponderaçăo prevalecer para o lado dos direitos femininos." Por fim, teve quem "(iii) tenha considerado a vida como valor preponderante (Cezar Peluso); ou, entâo, (iv) nem tenha admitido a ponderaçâo (Gilmar Mendes, Lewandowski)."

Denota-se que os Ministros Celso de Mello e Joaquim Barbosa entenderam que os direitos à liberdade, à autonomia, à privacidade, sexuais e reprodutivos da mulher seriam fundamento para a resoluçăo da demanda. Quanto, todavia, ao que fundamentaram ser autonomia da mulher nesse processo de decisáo sobre o aborto de feto anencéfalo, infere-se que o Ministro Marco Aurélio pontuou que o que se pretendeu foi assegurar à mulher o "direito de viver as suas escolhas, os seus valores, as suas crenças", visto que se tem nas máos o direito dela de se "autodeterminar, de escolher, de agir de acordo com a própria vontade num caso de absoluta inviabilidade de vida extrauterina." Sendo assim, "estăo em jogo, em última análise, a privacidade, a autonomia e a dignidade humana dessas mulheres." Para ele, ainda, o ato de obrigar a mulher a manter o feto seria equiparado ao cárcere privado de seu próprio corpo, de modo que a desproveria do "mínimo essencial de autodeterminaçâo e liberdade, assemelhando-se à tortura ou a um sacrifício que nâo pode ser pedido a qualquer pessoa ou dela exigido." (BRASIL, 2012, p. 68).

A Ministra Carmem Lúcia, em um tópico de seu voto que denominou "Estado Democrático de Direito e a dignidade da pessoa humana", citou Immanuel Kant (apud RABENHORST, 2001, p. 33) para descrever que "[...] a liberdade é mais do que a simples ausência de impedimentos externos. Livres sâo aqueles que fazem suas próprias escolhas, embasados em determinados princípios. Dessa forma, apenas os seres racionais gozam da liberdade." (BRASIL, 2012, p. 46). Referiu-se, ainda, a diversos autores que erigem a dignidade da pessoa humana como fundamento dos direitos fundamentais e também do qual emanam os demais direitos fundamentais, concluindo que há afronta à dignidade humana à maternidade ou paternidade exigida no ordenamento jurídico que "determina a continuidade de gestaçăo, da qual năo resultará, no estágio atual do conhecimento médico, ser humano com vida, o que afeta a personalidade daqueles que vivenciam a experiência, inclusive em sua relaçâo aos concidadáos por colocá-los em situaçăo de criminalidade." (BRASIL, 2012, p. 50).

Adotando esse posicionamento, a Ministra Rosa Weber, já no início de seu raciocínio, pontua sobre a liberdade do indivíduo, asseverando que todos sâo "livres para 
escolher os seus modos de vida e iguais em direitos e deveres para que possam desenvolver suas liberdades e respeitem os demais." (BRASIL, 2012, p. 115), e, nessa proposiçăo nâo se pode impor superioridade entre liberdade e igualdade, pois sâo condiçôes à convivência dos demais valores, de modo que a soluçăo para o caso é a aplicaçăo da fórmula da proporcionalidade em sentido estrito.

Explanou que os direitos constitucionais envolvidos no caso săo: direito de proteçăo (feto) contra direito de defesa (da gestante). E nessa divisáo das razôes, o quociente resulta a favor da liberdade da mulher em cotejo com a proteçáo do feto, visto que proteger a gestante nessa situaçăo é "garantir a sua liberdade de escolha sobre o papel reprodutivo que lhe cabe, reconhecendo-lhe direito fundamental." (BRASIL, 2012, p. 135).

O Ministro Joaquim Barbosa questionou se, diante da vida extrauterina inviável do feto, o direito à vida deve ser garantido ainda no mesmo grau de proteçăo? E concluiu e explicou que náo, isso porque "a norma penal chancela a liberdade da mulher de optar pela continuidade ou pela interrupçăo da gestaçăo." (BRASIL, 2012, p. 150). Na ponderaçâo entre os valores jurídicos tutelados pelo direito, "a vida extrauterina inviável e a liberdade e autonomia privada da mulher, prevalece a dignidade da mulher, deve prevalecer o direito de liberdade desta de escolher aquilo que melhor representa seus interesses pessoais, suas convicçóes morais e religiosas, seu sentimento pessoal." (BRASIL, 2012, p. 149).

Em oposiçăo aos argumentos dos demais mencionados, o Ministro Cezar Peluso, que votou pelo enquadramento da interrupçâo da gravidez anencefálica ao tipo delitivo do aborto, justificou que a liberdade e autonomia jurídicas năo podem ser aventadas para o caso, visto que há previsâo legal que tipifica a conduta. Para ele "a conduta censurada transpóe a esfera da autonomia e da liberdade individuais, enquanto implica, sem nenhum substrato de licitude, imposiçāo de pena capital ao feto anencefálico." (BRASIL, 2012, p. 383).

Pontuou, ademais, que o princípio da legalidade e a cláusula geral da liberdade "sâo limitados pela existência das leis constitucionais. Onde a lei o considera criminoso, e por isso proíbe certo comportamento, nâo há espaço de liberdade jurídica, năo há possibilidade teórica de invocaçâo do princípio da liberdade nem da legalidade. Já estâo pré-excluídos." (BRASIL, 2012, p. 384).

A partir do exposto, denota-se que o argumento da autonomia é comum aos ministros, apesar de eles năo a conceituarem isoladamente, apenas utilizando a situaçâo fática como argumento. Contudo, pode-se deduzir da linha de fundamentaçăo utilizada pelos julgadores que a concepçâo da definiçáo da autonomia é aquela adstrita à autonomia privada, como se demonstrará em tópico oportuno.

\subsection{DEBATE A RESPEITO DO DIREITO À VIDA VERSUS DIREITO(S) À AUTONOMIA, SEXUAIS E REPRODUTIVOS, À INTEGRIDADE FÍSICA E PSÍQUICA E À IGUALDADE APOSTOS NO HC 124.306}

A decisăo da Primeira Turma do Supremo Tribunal Federal adotou como razâo de decidir o voto-vista do Ministro Luís Roberto Barroso, no sentido de que a criminalizaçăo da descontinuaçấo da gravidez no primeiro trimestre contraria os direitos 
fundamentais da mulher, uma vez que năo observa suficientemente o princípio da proporcionalidade.

Ao afirmar a incompatibilidade da criminalizaçăo do aborto com a Constituiçăo, a premissa náo defende a disseminaçăo do procedimento, mas sim que ele seja raro e seguro, na medida em que o aborto é uma prática que se deve procurar evitar, pelas complexidades físicas, psíquicas e morais que envolve. No entanto, aliado a isso, é o papel do Estado e da sociedade ofertar educaçăo sexual, distribuiçăo de contraceptivos e amparo à mulher que almeje ter filho e que se encontre em circunstâncias adversas (BRASIL, 2016).

Pontuou, ademais, acerca da distinçăo e delicadeza da matéria, principalmente, diante das intervençôes políticas, econômicas, sociais e religiosas inevitáveis. Além do mais, como năo poderia deixar de fazer, situou os direitos fundamentais, vinculando os poderes estatais de modo a funcionar como uma reserva mínima de justiça às pessoas.

Ao iniciar, relembrou que "após a Segunda Guerra Mundial, os direitos fundamentais passaram a ser tratados como uma emanaçăo da dignidade humana, na linha de uma das proposiçóes do imperativo categórico kantiano: toda pessoa deve ser tratada como um fim em si mesmo, e năo um meio para satisfazer interesses de outrem ou coletivos." (BRASIL, 2016, p. 14).

Nesse sentido, assinalou que criminalizar a interrupçâo voluntária da gestaçâo feriria os direitos fundamentais das mulheres, atingindo brutalmente a sua dignidade, notadamente porque nada mais trágico e marcante para a mulher do que ter que decidir tal dilema, de modo que um processo criminal apenas tornaria sua vida ainda pior.

Isso porque se torna indispensável a análise do status jurídico do embriâo durante essa fase inicial da gestaçăo, para qual se tem duas posiçóes antagônicas: a que defende a existência da vida desde a concepçăo (fecundaçăo do óvulo pelo espermatozoide), e a da formação do sistema nervoso central e rudimentos de consciência ocorridos após o terceiro mês de gestaçăo.

Fato é que, segundo o Ministro, năo há previsăo legal que defina o status jurídico do embriăo e o início da vida. Sendo assim, pauta-se em escolhas religiosas ou filosóficas de cada um. No entanto, o que se deve considerar, nesse período, é que "năo há qualquer possibilidade de o embriấo subsistir fora do útero materno nesta fase de sua formaçáo. Ou seja: ele dependerá integralmente do corpo da mulher" (BRASIL, 2016, p. 17), de modo que a violaçâo de seus direitos fundamentais é incontestável.

Definida no texto do voto como "o poder de controlar o próprio corpo e de tomar as decisôes a ele relacionadas" (BRASIL, 2016, p. 17), a autonomia da gestante prevaleceu ao suposto direito à vida do feto, que neste triênio gestacional náo possui sistema nervoso central nem consciência, dependendo totalmente da mulher. Desse modo, ofenderia a liberdade individual da gestante, corolário da dignidade humana, à medida que o Estado impóe à mulher a obrigaçáo de permanecer com o feto que náo possui vida.

Afere-se ainda do voto que, diante da premissa de ausência de vida fetal durante os três primeiros meses, impor à mulher a manutençâo da gestaçâo seria como se "tratasse um útero a serviço da sociedade, e năo de uma pessoa autônoma, no gozo de plena capacidade de ser, pensar e viver a própria vida" (BRASIL, 2016, p. 17), já que nâo há choque entre direito à vida e direito à autonomia, pois ainda nâo há vida do feto, 
apenas liberdade da gestante em năo satisfazer interesses de outrem ou coletivos, mas sim a sua vontade.

Dos demais direitos violados, em relaçâo aos direitos sexuais e reprodutivos da mulher, utilizou Luís Roberto Barroso como referência o parágrafo 7.3 do Relatório da Conferência do Caio, devendo caber a ela a decisăo sobre se e quando deseja ter filhos, sem discriminaçăo, coerçăo e violência.

Ademais, porque cabe somente à mulher o ônus da gravidez, devem ser protegidos com maior intensidade a sua vontade e seus direitos, fundamento esse que serviu também para justificar o direito à integridade física e psíquica e à igualdade de gênero. Além do mais, possíveis agressóes ao direito à igualdade social săo inferidas, uma vez que a incidência das normas penais afeta de forma desproporcional as mulheres mais pobres, em razáo de sua condiçâo socioeconômica de acesso ao sistema de saúde e justiça, e também à educaçăo.

A Ministra Rosa Weber aduziu que dentre os questionamentos a serem feitos para a decisăo do caso, deve-se analisar se esse direito de escolha pode ser negado à mulher e quais seriam os princípios constitucionais em colisâo. Após citar casos emblemáticos da jurisdiçáo comparada ${ }^{8}$, concluiu, seguindo as premissas do ministro presidente, que o direito à vida, referendado na Constituiçấo Federal no artigo $5^{\circ}$, inciso XLVII, náo possui caráter absoluto. Corolário da disposiçăo constitucional, o Código Penal trouxe a excludente de ilicitude do aborto ético ou humanitário (resultado de estupro). Logo, entendeu a ministra que a "proporcionalidade da escolha política é controversa em face da tutela dos direitos fundamentais da mulher" (BRASIL, 2016, p. 15), de modo que, assim como houve a flexibilizaçâo política para garantir a possibilidade da interrupçâo da gestaçâo decorrente de estupro, independentemente de viabilidade ou năo do feto, bem como diante do fato de que nâo há direito absoluto, é possível a interpretaçāo dos artigos 124 a 126, do Código Penal, conforme o texto constitucional, afastando a criminalizaçăo da interrupçăo voluntária da gravidez, por decisăo da gestante, no primeiro triênio.

\section{A AUTONOMIA (PRIVADA?) ENQUANTO FUNDAMENTO BASILAR DAS DECISÕES DO SUPREMO TRIBUNAL FEDERAL NA ADPF 54 E NO HC 124.306}

Verifica-se que, apesar de formalmente iguais, existem distinçōes substancialmente importantes que representam mudança de significado aos termos autonomia e autonomia privada.

Etimologicamente, o termo autonomia tem o condăo de conferir a ideia de reger-se segundo suas próprias leis. Para a perspectiva kantiana, por sua vez, a definiçáo de autonomia decorre da concepçâo de dignidade da pessoa humana, cujo imperativo categórico repousa na ideia de que os seres irracionais têm apenas valor relativo

8 Roe versus Wade, em 1973. Griswold versus Connecticut, em 1965. Planned Parenthood of Southestern Pa. versus Casey, em 1992. Whole Woman's Health versus Hellerstedt, em 2016 - todos da Suprema Corte Americana. Caso Artavia-Murillo (Fecundación In Vitro) x Costa Rica, em 2012 - Corte Interamericana de Direitos Humanos. Casos Paton versus Reino Unido; Vo versus França; Evans versus Reino Unido; A, $B$ and $C$ versus Irlanda - todos da Corte Europeia de Direitos Humanos (BRASIL, 2016). 
como meios e, por isso, chamam-se coisas, enquanto que os seres quando racionais se chamam pessoas, "porque a sua natureza os distingue já como fins em si mesmos, quer dizer como algo que náo pode ser empregado como simples meio e que, por conseguinte, limita nessa medida todo o arbítrio." (KANT, 2009, p. 241).

Logo, autonomia para a perspectiva kantiana pode ser definida como "a propriedade da vontade de ser ela mesma sua lei", pela qual foi expressa por meio do imperativo categórico "age segundo a máxima tal que possas, ao mesmo tempo, querer que ela se torne lei universal" (KANT, 2009, p. 59), decorre intrinsecamente da dignidade da pessoa humana, a qual é um atributo inerente a todos os seres humanos pelo fato de serem dotados de racionalidade e autodeterminaçăo.

Nessa linha, Sarlet (2002, p. 33), a partir da concepçăo ambivalente de dignidade, ressalta que autonomia da vontade pode ser definida como "a faculdade de determinar a si mesmo e agir em conformidade com a representaçăo de certas leis, é um atributo apenas encontrado nos seres racionais, constituindo-se no fundamento da dignidade da natureza humana."

Além disso, enquanto integrante do elemento ético do conteúdo da dignidade da pessoa humana, na concepçáo tripartite ${ }^{9}$, proposta por Barroso (2010, p. 24), a autonomia consiste na "capacidade de autodeterminaçăo, o direito do indivíduo de decidir os rumos da própria vida e de desenvolver livremente sua personalidade. Significa o poder de fazer valoraçôes morais e escolhas existenciais sem imposiçóes externas indevidas."

O citado autor relembra a moral kantiana, pautada na ideia de que cada indivíduo dá a si mesmo a concepçăo daquilo que deve seguir, sem imposiçăo externa, contudo, aposta na autonomia do indivíduo, embasada na razâo, independência e escolha (CUNHA E CRUZ; BALBINOT, 2017).

Essa autonomia integra a essência da dignidade da pessoa humana, uma vez que a deixa livre de influências externas indevidas para, ao longo de sua vida, decidir e fazer escolhas conforme sua própria concepçâo de bem. Em sua dimensâo jurídica, no plano dos direitos individuais, a dignidade se desenvolve como autonomia privada, porque "presente no conteúdo essencial da liberdade, no direito de autodeterminaçấo sem interferências externas ilegítimas, nas possibilidades objetivas de decisâo e escolha", e, também, no plano político, quando a dignidade se expressa como "autonomia pública, identificando o direito de cada um participar no processo democrático." (BARROSO, 2010, p. 24).

Apesar disso, fato é que a autonomia é reconhecida, tanto na concepçâo de Ingo Wolfgang Sarlet (dimensăo dúplice) quanto na tripartite de Luís Roberto Barroso, como elemento da dignidade da pessoa humana. Todavia, esse reconhecimento de liberdade como corolário da dignidade năo confere ao indivíduo a irrestrita autonomia, à medida que a autonomia privada pode ser limitada pelo próprio valor que a dignidade

9 A concepçăo tripartite da dignidade proposta por Barroso (2010) aborda os três elementos essenciais à dignidade da pessoa humana: valor intrínseco, autonomia e valor social da pessoa humana. 0 valor intrínseco, que é o elemento ontológico da dignidade, está ligado à natureza do ser, ao que é comum e inerente a todos os seres humanos. A autonomia, por sua vez, à razáo e ao exercício da vontade na conformidade de determinadas normas. Enquanto que o valor social representa uma concepçâo ligada a valores compartilhados pela comunidade, segundo seus padróes civilizatórios ou seus ideais de vida boa. 
da pessoa humana possui (CUNHA E CRUZ; BALBINOT, 2017), disso a importância de saber a distinçáo entre autonomia (da vontade) e autonomia privada.

A autonomia da vontade repousa no ideal contratualista de vinculaçăo, isso porque, segundo os voluntaristas, a vontade gerava o negócio jurídico que, posteriormente, foi reconhecido năo só a vontade, mas necessitava da declaraçăo. Logo, para gerar efeitos jurídicos ao negócio, era necessária a declaraçâo de vontade, que nada mais era do que a exteriorizaçăo da liberdade de escolha do indivíduo (BORGES, 2005), pois a autonomia da vontade era identificada nessa relaçâo como "poder de criar e regular os efeitos jurídicos de sua contrataçấo, sem intervençấo externa: o contrato era uma esfera de livre atuaçăo dos particulares." (BERTI, 2014, p. 67).

Com essa constitucionalizaçâo do direito civil, situaçôes puramente de direito privado passam a ser alcançadas pelo princípio basilar da dignidade da pessoa humana e a partir daí as relaçóes privadas também passam a observar os preceitos decorrentes dos direitos fundamentais (BERTI, 2014).

Assim, questionou-se aquela ideia voluntarista de que o mero consentimento seria capaz de criar direito, uma vez que a vontade "é interna ao sujeito e năo pode ser reconhecível por outra pessoa e pelo ordenamento jurídico, existindo unicamente para a consciência da própria pessoa." (CUNHA E CRUZ; BALBINOT, 2017, p. 27).

E por decorrência disso, diante do reconhecimento indispensável da autonomia como corolário da dignidade da pessoa humana, fez-se necessária a "assimilaçáo da transiçăo" de autonomia da vontade para autonomia privada, pois a autonomia privada se vinculava diretamente aos valores constitucionais, de modo que se ligava à valorizaçâo da pessoa humana, no entanto limitada pela ordem jurídica, que norteia a forma, conteúdo, capacidade e legitimidade dos sujeitos (BORGES, 2005).

Logo, a autonomia privada oriunda do Estado Social segue a ideia de que as manifestaçóes de vontade necessitam de controle de juridicidade em virtude da desigualdade social substancialmente existente entre as pessoas, devendo ser inserida ao Estado Constitucional que visa garantir a liberdade dos indivíduos pautada nos demais princípios que regem as relaçóes (CUNHA E CRUZ; BALBINOT, 2017).

Infere-se que a autonomia privada nâo é irrestrita, ilimitada, "năo se permite exercitar o poder de disposiçâo sobre certas relaçóes ou sobre certos direitos" (BORGES, 2005, p. 56), pois essa limitaçâo tem o viés justamente de equilibrar o interesse da pessoa de um lado e o interesse de demais indivíduos do outro. Portanto, traduz-se a uma liberdade condicionada à dignidade da pessoa humana.

Nota-se, entăo, que autonomia, enquanto irrestrita e pautada única e exclusivamente na vontade do indivíduo, náo pode ser objeto de imposiçấo de limites, de modo que, muitas vezes, fere a dignidade da pessoa humana que a expressa quando colide com direitos protegidos. No entanto, a autonomia privada, por pautar-se na dignidade da pessoa humana, admite que essa liberdade seja condicionada ao respeito e năo ofensa à dignidade.

Assim, denota-se que os ministros, ao julgarem ambos os casos aventados - ADPF 54 e o HC 124.306 -, analisaram esse limite de disposiçăo que a mulher tem quando sua vontade colide com a proteçăo de um direito do feto. Os que adentraram no argumento da autonomia como fundamento para as razóes de decidir fizeram-no, primeiramente, 
considerando que os direitos constitucionais náo săo absolutos, de modo que o alcance da autonomia da mulher deveria ser analisado à luz da (in)viabilidade de vida do feto.

Importante observaçăo deve ser feita em relaçăo à vinculaçăo do Ministro Luís Roberto Barroso em ambos os processos, possuindo ponto de destaque seu posicionamento, isso porque, na ADPF 54, apesar de năo ser integrante da corte na época, foi ele, enquanto advogado, o representante da Confederaçăo Nacional dos Trabalhadores na Saúde, tendo sido vários de seus argumentos considerados e utilizados para o decisum.

Além disso, referente ao HC 124.306, o voto-vista proferido pelo Ministro foi o condutor do julgamento, de modo que suas proposiçóes foram seguidas pela maioria dos julgadores, sendo relevantes à análise.

No conteúdo técnico voltado para a (in)viabilidade de vida, verificou-se que tanto o feto anencéfalo quanto até o primeiro trimestre de gestaçăo a viabilidade de vida năo existe. $O$ primeiro porque acaso se desenvolva até nascer, nâo sobreviverá mais do que algumas horas após o parto; e o segundo em virtude de que até esse período náo há desenvolvimento do sistema nervoso central e rudimentos de consciência e, acaso nasça nessa idade, năo possui condiçấo alguma de desenvolver-se.

Já no que diz respeito, entâo, ao ponto jurídico-moral que se refere à autonomia, segundo a definiçấo elaborada por Barroso (2014, p. 64), dignidade humana "é um princípio jurídico com status constitucional, e năo como um direito autônomo [...] funciona tanto como justificaçăo moral quanto como fundamento jurídico-normativo dos direitos fundamentais ${ }^{10} . "$

A partir dessa concepçăo, considera que para tal fim é necessária a observância de um conteúdo mínimo (concepçăo minimalista), que entăo fundamentará a definiçăo de dignidade humana, qual seja: "1. Valor intrínseco de todos os seres humanos; 2. A autonomia de cada indivíduo; e 3. Limitada por algumas restriçōes legítimas impostas a ela em nome de valores sociais ou interesses estatais (valor comunitário)." (BARROSO, 2014, p. 72).

Quanto ao valor intrínseco dos seres humanos, adstrito a todos, corresponde aos traços e características inerentes à natureza humana, como inteligência, sensibilidade e comunicaçăo, fato que os torna superiores e únicos. A autonomia envolve, por sua vez, o aspecto ético da dignidade, uma vez que permite ao indivíduo buscar em si a sua autodeterminaçấo. E o valor comunitário representa o conteúdo social da dignidade, moldado a partir da vinculaçâo do indivíduo com os demais (BARROSO, 2014).

Infere-se, desse modo, que para o Ministro Luís Roberto Barroso a autonomia é elemento ético da dignidade da pessoa humana e pressupóe o preenchimento de três requisitos para que seja considerada desenvolvida em inteira observância à dignidade: razăo, independência e escolha (BARROSO, 2014).

Além disso, a autonomia privada, enquanto elemento essencial da dignidade humana, contém a importante delimitaçâo para que haja um sopesamento em casos de situaçôes em que há contradiçâo de normas, visando equilibrá-las e adequá-las

10 O autor repisa impossibilidade de elaborar com louvor um conceito transnacional de dignidade humana, na medida em que é impossível levar em conta os aspectos religiosos, históricos e políticos de todos os povos para que se conseguisse definir, em um conceito único, dignidade humana (BARROSO, 2014). 
às circunstâncias. E, desse modo, a autonomia se refere à ideia da qual os indivíduos dependem para poderem ser "livres da necessidade"11, ou seja, que as necessidade vitais essenciais sejam observadas, e, para tanto, os indivíduos precisam "estar além de limiares mínimos de bem-estar, sob pena de a autonomia se tornar uma mera ficçăo, e a verdadeira dignidade humana nâo existir." (BARROSO, 2014, p. 85).

Ademais, infere-se um valor comunitário adstrito à autonomia, de modo a estabelecer uma restriçâo quando há um choque de valores fundamentais, e segundo o Ministro essa restriçâo se realiza com a observância de três objetivos: "1. A proteçâo dos direitos e da dignidade de terceiros; 2. A proteçăo dos direitos e da dignidade do próprio indivíduo; e 3. A proteçâo dos valores sociais compartilhados." (BARROSO, 2014, p. 88).

Sendo assim, a limitaçấo da autonomia privada da mulher para dispor sobre a gestaçăo apenas nesses casos de inviabilidade de vida do feto, e nâo a deixando livre irrestritamente para decidir acerca da manutençáo ou nâo de qualquer gravidez, pautou-se na concepçâo de autonomia privada, já que analisou a liberdade da mulher em consonância com a dignidade da pessoa humana.

Complementarmente, e por fim, por năo ser viável a vida extrauterina do feto em ambos os casos analisados - no de anencefalia em razăo da ausência de condiçấo cerebral central para o desenvolvido, e até o primeiro trimestre da gestaçăo porque nesse período o feto depende inteiramente do corpo materno, sendo expelido por qualquer motivo, năo há chance de sobrevida -, as razóes pautaram-se na inexistência, nesse caso, de proteçáo dos direitos e da dignidade de terceiros (fetos), de modo que náo se deveria cogitar a restriçâo ou flexibilizaçăo da autonomia da gestante, justamente pela inviabilidade da vida extrauterina do mesmo.

\section{CONSIDERAÇÕES FINAIS}

O julgamento da Arguiçâo de Descumprimento de Preceito Fundamental n. 54 e do Habeas Corpus n. 124.306, ambos do Supremo Tribunal Federal, nos quais se discutiu sobre a (im)possibilidade de interrupçăo da gestaçăo em caso de gravidez de feto anencefálico ou durante o primeiro triênio gestacional, năo fugiu dos holofotes diante da importância que o tema tem.

A descontinuaçăo da gravidez, foco da temática, levou à corte suprema brasileira a se manifestar, sendo que, com pontos de vistas e análises distintas, alguns ministros detectaram a colisăo, mesmo que aparente, de direitos fundamentais, como a vida do feto e a autonomia da gestante, objeto de análise deste trabalho. Fato é que aqueles que adentraram na análise da autonomia da mulher construíram seus argumentos pautados na liberdade kantiana, no entanto, reconheceram a necessária limitaçâo dessa liberdade para que ela năo se torne irrestrita e enseje a disposiçăo de toda e qualquer gestaçăo.

11 A expressâo "livres da necessidade", do inglês free from want, foi utilizada no discurso do presidente Franklin D. Roosevelt, de 14 de janeiro de 1941, quando propôs "quatro liberdades que as pessoas 'de todos os lugares do mundo' deveriam desfrutar, o que incluía a liberdade de expressáo (freedom of speech), liberdade de culto (freedom of worship), liberdade das necessidades (freedom from want) e liberdade do medo (freedom from fear)." (BARROSO, 2014, p. 85). 
Denotou-se, entâo, que a concepçăo adotada pelos julgadores foi a de autonomia privada, uma vez que diante da inviabilidade de vida extrauterina do feto deve prevalecer a autonomia da gestante para decidir livremente sobre a manutençâo ou nâo da gestaçấo anômala, de modo que o ideal de liberdade utilizado esteve inter-relacionado com a dignidade da pessoa humana, respeitando os limites dessa dignidade e sobrelevando, nesse caso, a autonomia.

Ademais, a inviabilidade da vida extrauterina do feto representou a desnecessária proteçấo dos direitos e da dignidade de terceiros (fetos), de modo que náo se cogitou ferir o valor comunitário ao qual a autonomia privada da gestante está interligada, năo havendo restriçăo ou flexibilizaçăo da autonomia da gestante, justamente pela inviabilidade da vida extrauterina do feto.

Nota-se, entăo, que no julgamento da APDF 54 e do HC 124.306, uma parcela importante dos julgadores, notadamente pautados nos argumentos aventados pelo Ministro Luís Roberto Barroso, utilizou a concepçâo de autonomia privada para as razôes da decisăo, apesar de se verificar que as referências ocorreram apenas ao termo autonomia, no entanto, com conteúdo característico da autonomia privada da gestante, possibilitando-se livremente dispor a respeito da descontinuaçáo da gravidez do feto anencéfalo e até o primeiro trimestre, contudo, sem torná-la ilimitada, porquanto a análise se limitou à inviabilidade extrauterina do feto, năo se permitindo uma disposiçâo irrestrita de toda e qualquer gestaçâo. 


\section{REFERÊNCIAS}

BARROSO, Luís Roberto. A dignidade da pessoa humana no direito constitucional contemporâneos: natureza jurídica, conteúdos mínimos e critérios de aplicaçâo. Dez. 2010. Disponível em: <http://luisrobertobarroso.com.br/wp-content/uploads/2016/06/ Dignidade_texto-base_11dez2010.pdf>. Acesso em: 7 jan. 2018.

BARROSO, Luís Roberto. A dignidade da pessoa humana no direito constitucional contemporâneo: a construçăo de um conceito jurídico à luz da jurisprudência mundial. Belo Horizonte: Fórum, 2014.

BERTI, Natália. Da autonomia da vontade à autonomia privada: um enfoque sob o paradigma da pós-modernidade. Revista de Direito Privado, v. 57, p. 69-94, jan./mar. 2014.

BORGES, Roxana Cardoso Brasileiro. Disponibilidade dos direitos de personalidade e autonomia privada. Săo Paulo: Saraiva, 2005.

BRASIL. Decreto-Lei n. 2.848, de 7 de dezembro de 1940. Código Penal. Brasília, DF: Senado Federal, 1940. Disponível em: <http://www.planalto.gov.br/ccivil_03/decreto-lei/Del2848compilado.htm>. Acesso em: 4 jan. 2018.

BRASIL. Decreto-Lei n. 3.689, de 3 de outubro de 1941. Código de Processo Penal. Brasília, DF: Senado Federal, 1941. Disponível em: <http://www.planalto.gov.br/ccivil_03/decreto-lei/Del3689.htm>. Acesso em: 4 jan. 2018.

BRASIL. Constituição da República Federativa do Brasil de 1988. Brasília, DF: Senado Federal, 1988.

BRASIL. Lei n. 9.434, de 4 de fevereiro de 1997. Dispóe sobre a remoçăo de órgâos, tecidos e partes do corpo humano para fins de transplante e tratamento e dá outras providências. Brasília, DF: Senado Federal, 1997. Disponível em: <http://www.planalto.gov.br/ ccivil_03/leis/19434.htm>. Acesso em: 4 jan. 2018.

BRASIL. Supremo Tribunal Federal. ADI 3.510. Relator: Ministro Ayres Britto. Órgâo Julgador: Plenário. Julgamento em 29 maio 2008. Brasília, DF, 30 maio 2008. Disponível em:〈http://redir.stf.jus.br/paginadorpub/paginador.jsp?docTP=AC\&docID=611723〉. Acesso em: 4 jan. 2018.

BRASIL. Supremo Tribunal Federal.ADPF 54. Relator: Ministro Marco Aurélio. Órgăo Julgador: Plenário. Julgamento em 12 abr. 2012. Brasília, DF, 14 abr. 2012. Disponível em: ‘http://redir. stf.jus.br/paginadorpub/paginador.jsp?docTP=TP\&docID=3707334>. Acesso em: 4 jan. 2018.

BRASIL. Superior Tribunal de Justiça. HC n. 290.341. Brasília, DF, 04 set. 2014. Disponível em:<https://ww2.stj.jus.br/processo/revista/documento/mediado/?componente= ATC\&sequencial=38597372\&num_registro=201400534269\&data=20140916\&tipo=5\&formato=PDF $>$. Acesso em: 11 jan. 2018. 
BRASIL. Supremo Tribunal Federal. Habeas Corpus 124.306. Relator: Ministro Luís Roberto Barroso. Órgāo Julgador: Primeira Turma. julgamento em 09 ago. 2016. Rio de Janeiro, 29 nov. 2016. Disponível em: <http://redir.stf.jus.br/paginadorpub/paginador. jsp?docTP=TP\&docID=12580345>. Acesso em: 4 jan. 2018.

BRASIL. Supremo Tribunal Federal. ADPF n. 442. Brasília, DF, 06 mar. 2017. Disponível em: 〈https://www.conjur.com.br/dl/psol-stf-descriminalize-aborto-meses.pdf〉. Acesso em: 11 jan. 2018.

CUNHA E CRUZ, Marco Aurélio Rodrigues da; BALBINOT, Jéssica. Autonomia da vontade, autonomia privada e o caso "lulu". Revista Jurídica UNI7, Fortaleza, n. 14, n. 1, p. 13-34, jan./jun. 2017. Disponível em: <http://www.uni7setembro.edu.br/periodicos/index.php/ revistajuridica/article/download/268/291/.>. Acesso em: 20 dez. 2017.

KANT, Immanuel. Fundamentaçāo da metafísica dos costumes - segunda seçâo: transiçâo da filosofia moral popular à metafísica dos costumes. Traduçâo Guido Antônio de Almeida. Săo Paulo: Discurso Editorial; Barcarolla, 2009.

MARCHIORI, Carolina Milani. Análise da ADPF 54: mapeamento da decisăo e verificaçâo de uma possível formaçáo de precedente. 103 f. Monografia (Pós-Graduaçâo) - Escola de Formaçấo da Sociedade Brasileira de Direito Público, Săo Paulo, 2012. Disponível em: <http://www.sbdp.org.br/arquivos/monografia/210_MONOGRAFIA3.pdf〉. Acesso em: 6 jan. 2018.

MELLO, Luciana Ferreira; BARBOZA, Estefânia Maria de Queiroz. Paralelo entre os precedentes dos Estados Unidos - análise da decisâo ROE versus WASE, e o Instituto da Eficácia Transcendente dos Motivos Determinantes no Brasil - análise da decisāo proferida pelo STF na ADPF n. 54. Espaço Jurídico Journal of Law [EJJL], [S.l.], v. 16, n. 1, p. 221-238, jan./jun. 2015. E-ISSN 2179-7943. Disponível em: <http://editora.unoesc.edu. br/index.php/espacojuridico/article/view/3739>. Acesso em: 9 jan. 2018.

RABENHORST, Eduardo Ramalho. Dignidade humana e moralidade democrática. Brasília: Brasília Jurídica, 2001.

SARLET, Ingo Wolfgang. Dignidade (da pessoa) humana e direitos fundamentais na Constituiçāo Federal de 1988. Porto Alegre: Livraria do Advogado Editora, 2002.

STEINMETZ, Wilson; RECKZIEGEL, Janaína. Crime de aborto e interrupçâo voluntária da gestaçấo no primeiro trimestre: análise da decisâo do Supremo Tribunal Federal no Habeas Corpus 124.306. Espaço Jurídico Journal of Law [EJJL], [S.1.], v. 18, n. 3, p. 763-766, set./dez. 2017. E-ISSN 2179-7943. Disponível em: <http://editora.unoesc.edu.br/index. php/espacojuridico/article/view/16270/pdf>. Acesso em: 9 jan. 2018. 